\title{
ループ状だ円振動子を用いた微小・薄箔材の群体搬送機構の検討*
}

\author{
笹木 亮*1, 小泉 邦 雄*1 \\ 佐々木 基文*1, 木下功 $土^{* 2}$
}

\section{Cluster Feeder Using Loop Type Elliptic Resonator for Foil Objects}

\author{
Tohru SASAKI*3, Kunio KOIZUMI, \\ Motofumi SASAKI and Kouji KINOSHITA \\ ${ }^{* 3}$ Graduate School of Science and Engineering, University of Toyama, \\ 3190 Gofuku, Toyama-shi, Toyama, 930-8555 Japan
}

\begin{abstract}
This paper deals with cluster feeding mechanism using loop type resonator's train. The resonator consists of loop and leg part, respectively. Each part was actuated by bimorph type piezoelectric members. The deflection of loop part and the bending of leg part generated by piezoelectric bimorphs makes an elliptic motion at the center point of the upper member. If resonators are put in a train and are actuated at the same frequency, it can feed objects on the upper surface of its train. The trial feeder, we developed, consists of 8 resonators ( 4 resonator pair). It could generate elliptic motion in arbitrary phase and could feed thin or soft objects that could not be fed with usual feeders. The feeding speed, that is obtained by dividing the feeding distance at the feeding time with camera vision, changed by phase shift of the input to leg part $(z)$ with the input to loop part $(y)$. The principle of feeding with the cluster feeder was clarified, and it was shown that the theoretical feeding speed fairly agree with the experimental ones. The cluster feeder can feed a thin or a soft object without damaging.
\end{abstract}

Key Words: Feeding Mechanism, Vibration of Mechanism, Coupled Vibration, Piezo-Element

\section{1. 緒言}

今日，精密機械・電子技術やバイオ技術の発達によ り，高機能性を有する新素材が多く開発され，またそ れらを用いた機器・デバイスの開発が進んでいる．こ れら機能性素材などに代表される新素材は, 従来の機 械技術で多く扱われてきた金属材料と異なり，柔軟か つ不定形で軟粘性を持つ物が少なくない. また, 高集 積化・高密度化技術に用いられることで, 部品の微小 化・薄箔化が進み, 従来の搬送技術では搬送面に吸着 したり，搬送中に破損してしまうなどしてハンドリン グが困難となるものが増えている.

これらを背景に，新素材・新材料に対応する搬送技 術が多く研究されている．柔軟物のハンドリングでは， 高分子フィルムを用いることで振動子自体を柔軟なも のとするアクチュエータ (1)や, 衣料品や食品を対象に し，視覚と力覚センサを用いて柔軟物の把持を可能と する研究 ${ }^{(2)}$ が行われている. 一方, 微小物のハンドリ ングに対しては, 加工・組立装置自体を小型化するマ イクロファクトリ ${ }^{(3)}$ などの研究が進められている.

* 原稿受付 2006 年 9 月 25 日.

*1 正員, 富山大学大学院理工学研究部( 930 -8555 富山市五 福 3190).

*2 正員, 富山大学工学部.

E-mail : tsasaki@eng.u-toyama.ac.jp
これらの技術は，従来のハンドリング技術の応用範 囲を拡大するものとして期待されているが，本格的な 実用化には至っていない，そこで本研究では，難供給 物の 1 つである微小・薄馢材や, 軟粘体のハンドリン グを実現するため, 任意のだ円振動を発生できる振動 子を図 1 のように複数個並べ,振動子上面を搬送面と して物体を搬送する群体型フィーダを開発した．その 駆動要素として, 上下方向に振動する門形部材と水平 方向に振動する脚部材を接合するか，または均一部材 を門形に成形し，柱となる部分を直交にひねることで, 別方向の 2 つの振動が独立に駆動できる振動子を考案

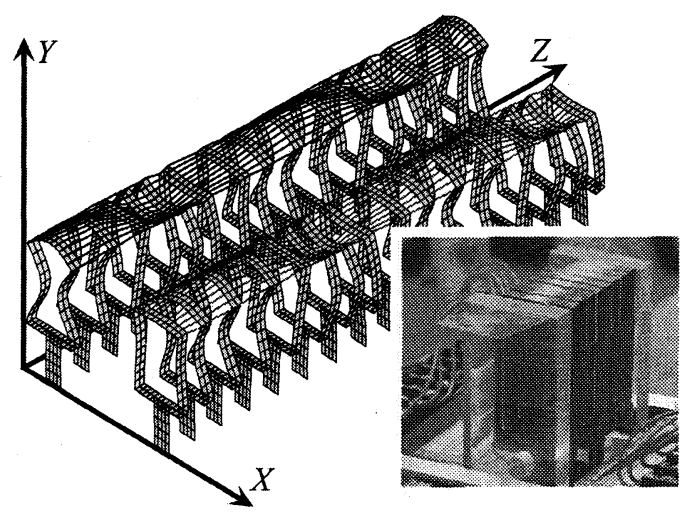

Fig.1 Feeder of resonator's train 


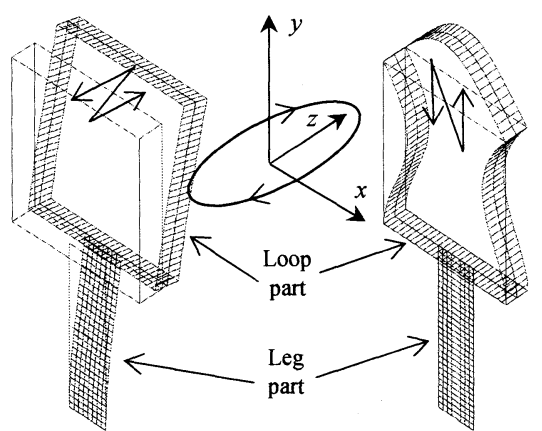

(a) Loop bending mode Fig.2 Natural modes of resonator

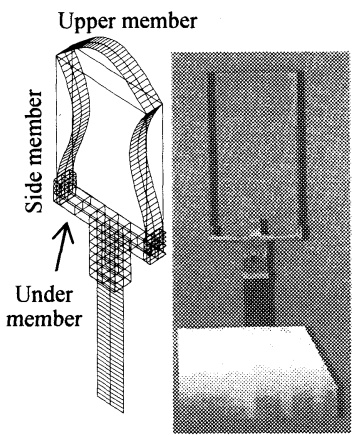

(a) Arch type

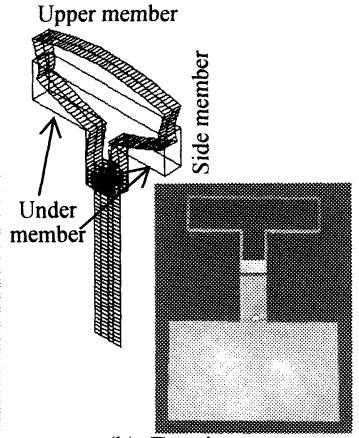

(b) T-script type

Fig.3 Shape of resonators

また，各々の振動子への入力の位相を変化させること で，搬送面上に任意のだ円振動を発生でき，搬送方向 を切換えたり，搬送物に応じた搬送形態を作り出すこ とが可能である. 加えて振動子はループ部材の剛性を 変化させることで駆動形態が可変である. 図 3(a)はル ープ部下部材を高剛性とすることで上部材中央に大振 幅を得るタイプであり，図3(b)は下部材を低剛性とす ることで搬送面である上部材面振幅分布の平坦さを得 ることを狙ったものである.

\section{2 連成振動抑止のための振動子対 ${ }^{(4)}$ 振動子} を群体搬送機構とするためには, 複数の振動子を近接 して設置した状態で任意のだ円振動を発生できること が条件となる. しかし, 各振動子は同一振動数で駆動 するため, 近接した状態では他の振動子を励振してし まい，任意の位相制御が不可能になる.

そこで, 高剛性の固定が無くとも固有モードを発生 できる構造として，2 個の振動子を固定部で 1 体とし 図 4(a)のような音叉のようなモードで振動させる. 2 個の振動子の水平方向振動が互いに逆相で振れ, その 固有振動数は固定の状態により変化しないため, 単一 振動子の片持ちはりのモードと同様に扱える.ゆえに， 振動子を対にすることで, 他の振動子への振動伝達を 抑えることができる. また，対自体に防振を施すこと が可能であり, 振動子対を並べた際も振動絶縁が可能 となる。これより，振動子を近接して並べた状態で, 任意のだ円振動が発生できる.

図 4(b)に搬送形態の 1 例を示す．緎毛が物体を送る ような動きとなり，進行波型とは異なり搬送面上に形 成される波の進行方向は搬送方向と同じとなる，また， 振動子対の配置も直線上だけではなく，曲線や円形状， さらには振動子対を上下に配置したり, 分岐させるこ とも可能である. 各振動子対を搬送物の特性に合った 搬送形態にすることで，1つの搬送機構で様々な搬送 物に対応できるほか，局部的に搬送形態を変化できる ため，異なる搬送物を連続して搬送できることなど， 


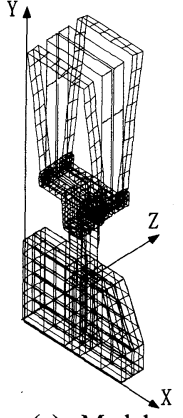

(a) Model
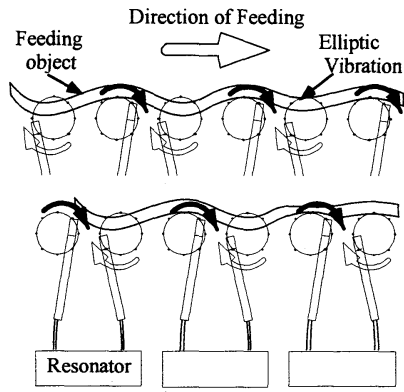

(b) Feeding with train

Fig.4 Pair resonator's train

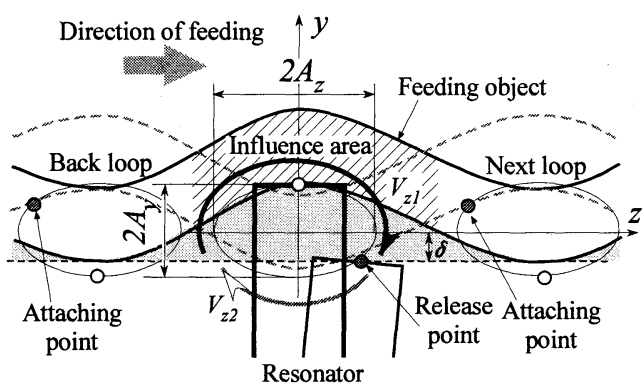

Fig.5 Principle of feeding

他の搬送機構には無いフレキシブルさを有する.

\section{3. 搬送速度}

搬送面上における搬送物との接触点の変位は，図 5 のようにだ円振動の $y$ 方向振幅を $A_{y}, z$ 方向振幅を $A_{z}, y$ 方向振幅に対する $z$ 方向振幅の位相ずれを $\phi$, 駆動振動数を $\omega$ とすると次式のように表せる.

$$
\begin{aligned}
& y=A_{y} \sin (\omega t) \\
& z=A_{z} \sin (\omega t-\phi)
\end{aligned}
$$

ここで搬送物は帯状で薄く低剛性であり，複数の振 動子に支持されて搬送されることから，各振動子に影 響を受ける領域を, 微小区間毎に区切られた質量と仮 定する. また, 薄く低剛性の搬送物の場合, 変形を生 じるため, 静止状態の搬送面高さを $y=0$ とおき, $y=-\delta$ より上で搬送物と接触すると仮定する. よって 搬送物がだ円振動により搬送力を受けるのは， $y=-\delta$ より上に搬送面がある場合であり，このとき搬送物が 跳躍しないとすれば微小区間は搬送面と一体となって 搬送される.この際の搬送速度 $V_{z 1}$ は微小区間の搬送 方向速度と同じとなり, $\delta / A_{y}=\cos \gamma$ とおくと(2)式か ら $\omega t=3 / 2 \pi+\gamma \rightarrow 3 / 2 \pi-\gamma$ の間で次式が成り立つ

$V_{z 1}=\dot{z}=A_{z} \omega \cos (\omega t-\phi)$

一方, $y<-\delta$ の時, すなわち微小区間が直下の振動 子と接触しない場合は, 隣り合う振動子により影響を 受ける. 直下の振動子と分離した瞬間に, 両端は既に
隣り合う振動子と接触しており,搬送面と一体となり運 動している．搬送物は極めて低剛性であり搬送方向に 伸縮するため, 両端に引っ張れられて自由運動すると 仮定すれば，隣り合う振動子の位相は $\pi$ ずれているた め, 分離の瞬間に微小区間は速度 $\dot{z}(\omega t=\pi / 2-\gamma)$ を受 ける. よって, この間の速度 $V_{z 2}$ は次式で表される.

$$
V_{z 2}=\dot{z}(\omega t=\pi / 2-\gamma)=A_{z} \omega \sin (\phi+\gamma)
$$

(3)式および(4)式より, $\omega t=\theta$ とおいて 1 周期におけ る平均搬送速度を求めると次式を得る。

$$
\begin{aligned}
V_{A V G} & =\frac{1}{2 \pi}\left\{\int_{0}^{\frac{3}{2} \pi-\gamma} \dot{z}(\theta) \cdot d \theta+\int_{\frac{\beta}{2} \pi+\gamma}^{2 \pi} \dot{z}(\theta) \cdot d \theta+2 \gamma \cdot V_{Z 2}\right\}_{(5)} \\
& =\frac{A_{z} \omega}{\pi}\{\sin \phi \sin \gamma+\gamma \cdot \sin (\phi+\gamma)\}
\end{aligned}
$$

上式のように，平均搬送速度 $V_{A V G}$ は $y$ 方向振幅に対す る $z$ 方向振幅の位相ずれ $\phi$ で最大となる值を有し, $\gamma=\pi / 2, A_{y}=A_{z}$ のとき $\phi \fallingdotseq 32.5^{\circ}$ で最大となる.

搬送物が帯状ではなく，搬送方向長さが振動子に対 して短く，複数個の振動子で搬送物が支持できない場 合, 搬送物に作用する振動子は単独となるため, 図 4(b)のように各振動子が搬送物を受け渡すような搬送 ができない。このような状態では搬送物は主に跳躍状 態で搬送される(5). このときの搬送速度は搬送物が跳 躍する瞬間の速度とほぼ同一となるため, 搬送速度が 最大になる位相条件は， $\gamma=\pi / 2$ の場合， $V_{z 2}$ が最大 となる $\phi=0$ もしくは $\pi$ である.

また，帯状搬送物においても搬送中に跳躍現象が生 じる場合，(5)式における第 2 項の影響が増大し，搬送 速度は搬送中の跳躍時間の割合に応じて, $V_{A V G}$ が最大 となる $\phi$ と, $V_{z 2}$ が最大となる $\phi=0$ もしくは $\pi$ の中間 值で最大となる.

\section{4. 群体搬送機構}

\section{1 試作した振動子と搬送機構図 3(a)，(b)に} 示す 2 種類の振動子をそれぞれ試作した. 微小・薄䈃 材が搬送対象のため, 小さな搬送機構が望ましく, 本 機構は $10 \mathrm{~cm}$ 角内に納まるスケールとした. ループ部 の上部材と横部材はりん青銅板 $(5 \times \mathrm{t} 0.3 \mathrm{~mm})$ を門形 に曲げ成形し，ピエゾセラミックス板（t0.2mm）を横 部材に貼りバイモルフ構造とした. 脚部も同じく鋼材 （t2mm）にピエゾセラミックス板を貼ってバイモル フ構造としている．鋼材（t1mm）を 2 個の振動子の 固定部にスペーサとして挟み, 振動子対を構成する. この振動子対を並べフィーダを構成する. 振動子対間 は対同士の振動伝達を抑えるため, スペーサとしてゴ ムシート（t $1 \mathrm{~mm} ）$ を挟んだ. 振動子全体は固定部の 穴にボルトを通し，スペーサがつぶれない程度に軽く 


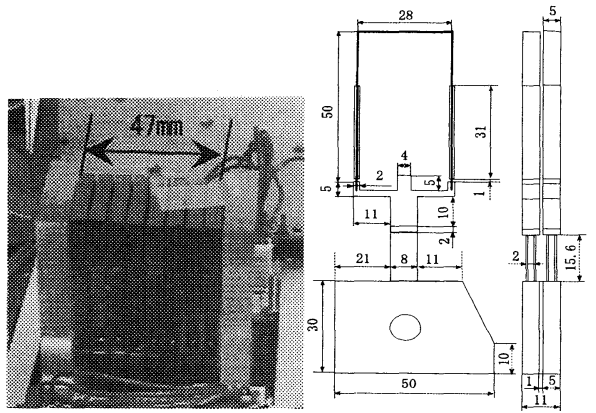

(a) Arch type

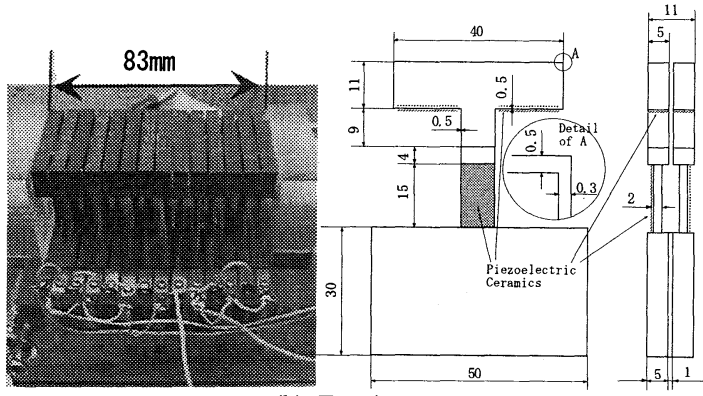

(b) T-script type

Fig.6 Construction of feeder

固定し，振動伝達防止のためゴムシート（t mm）上 に設置した．図 6(a)に示すアーチ型では振動子対を 4 対（振動子 8 個），同図(b)に示す $\mathrm{T}$ 字型は 7 対（振動 子 14 個）を並べ振動子群を構成して搬送機構とした。

\section{2 群体機構による搬送実験＼cjkstart測定装置の構成}

を図 7 に示す. 各振動子の搬送面における $y, z$ 方向 振幅は光ファイバー型変位計により測定し，だ円振動 形状は振動子列横方向から読み取り顕微鏡等で測定し た. 振動子は, 発振器からの基準正弦波を多チャンネ ル移相回路に入力し, その出力を各アンプを介し増幅 して振動子を励振する.このとき各振動子の変位出力 は電圧入力に対し，それぞれ異なる位相ずれを持つた め, 個々に入力する位相を調整する必要がある.

このため, 振動子の $y, z$ 方向の振幅と位相が全て 同じになるように，搬送方向上流から 1 番目の上流側 の振動子 A（No.1A）を基準とし，各チャンネル毎に位 相を調整した. 振幅はバイモルフ部材の最大許容印加 電圧より $y, z$ 方向共に複振幅 $100 \mu \mathrm{m}$ とし, 駆動周 波数は設計值より決定される固有振動数（アーチ型は $360 \mathrm{~Hz}, \mathrm{~T}$ 字型は $446 \mathrm{~Hz}$ ) で, 振動子群を駆動した ${ }^{(6)}$. $z$ 方向の $y$ 方向に対する位相ずれ $\phi$ を変えて, だ円振 動の形状を変化させたときの搬送速度を測定した. 入 力する位相は全ての振動子が同じ方向に直線振動する 位相を基準の $0^{\circ}$ とし， $\phi$ を $0 \sim 180^{\circ}$ まで変化させた. $180 \sim 360^{\circ}$ では進行方向が逆転する.

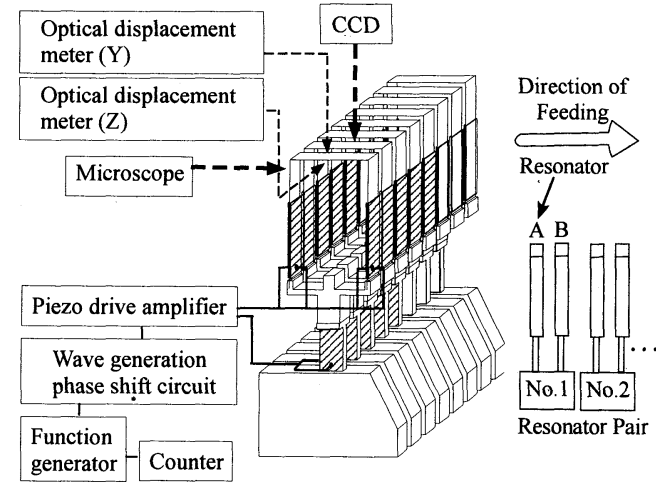

Fig.7 Measurement appratus

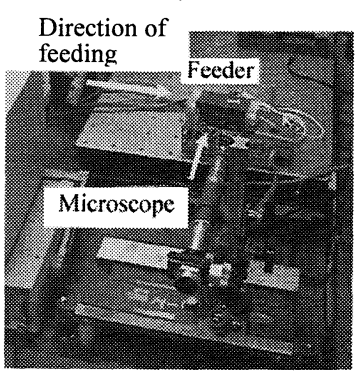

(a) Microscope

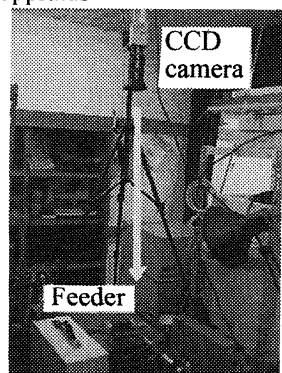

(b) CCD camera
Fig.8 Position of measurement appratus

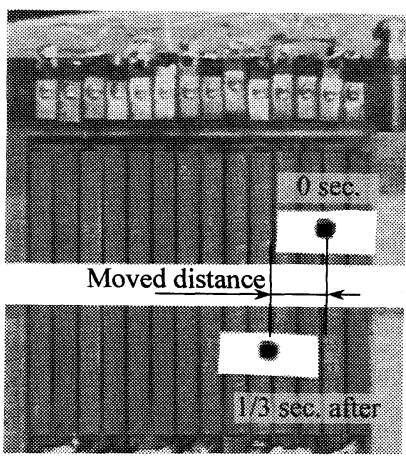

Fig.9 Measurement method of feeding object's speed 測定装置の位置関係を図 8 に示す，搬送速度は，ス卜 ロボライトを $1 / 6 \sim 1 / 15$ 秒間隔で発光させつつ, 搬送 試料の動きを搬送面上方より CCD カメラで撮影し，画 像解析装置（株式会社ライブラリー）により，撮影画 像における搬送試料の移動距離を撮影周期で除して求 めた. 図 9 に画像解析装置での測定の様子を示す. 搬 送試料に付けた黒点を測定点とした．搬送試料は搬送 困難物とされる薄箔材として金属䈃（金，ニッケル， チタン)，柔軟物としてゴムシート(シリコン，ラテ ックス), 軟粘性を持つ試料として食品（ハム，ライ スペーパー，餅皮）を用いた。

4.3 位相ずれによる搬送速度の変化 位相ずれによ 


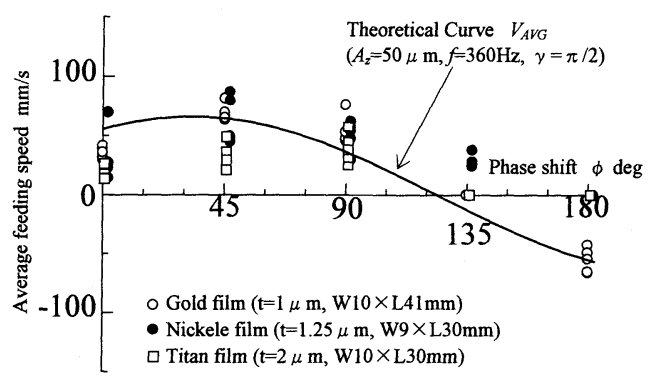

Fig.10 Feeding speed of shin objects

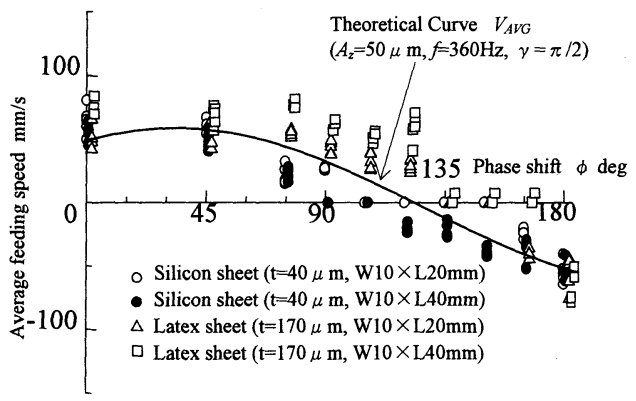

Fig.11 Feeding speed of soft objects

る搬送速度の変化を図 10〜12 に示す. 振動子には, 大振幅が発生可能なアーチ型を用いた．図10より薄 箔材を搬送試料とした場合，厚さ $1 \mu \mathrm{m}$ の金䈃を損傷 することなく搬送可能であった．また，その搬送速度 は $\phi$ ，すなわち発生するだ円振動の主軸の傾きにより 変化している，その傾向は実線で示す 3. 搬送速度の

(5)式による理論平均搬送速度とほぼ近似を取ってお り，先の搬送モデルの妥当性を裏付けるものである.

図 11 は柔軟物を搬送試料とした場合であり，厚さ $40 \mu \mathrm{m}$ のシリコンゴムシートが搬送可能であった. 試 料は搬送方向に $20 \mathrm{~mm}$ 程度のものまで搬送可能であり， それ以下の試料では搬送不可となる場合があった.こ れは長さが $10 \mathrm{~mm}$ 程度の試料は, 隣り合う 2 つの振動 子上にのみ接地するため, 逆位相のだ円振動が両端に 作用することで, 搬送のためのだ円振動の摩擦力が相 殺され, 搬送不可となるためと考えられる. また搬送 可能となる場合は, だ円振動による $z$ 方向への摩擦力 の影響が小さく，跳躍による搬送効果がより大きくな るためと考えられる. 試料の搬送方向長さが $20 \mathrm{~mm}$ 以 上では，試料の長さによって搬送速度に違いが見られ ず，搬送試料が 3 つ以上の振動子上に在る状態では, 試料の搬送方向長さは搬送速度に影響が無いと言える。 ラテックスでは図 10 の金属䇴とほぼ同様に理論平均 搬送速度と同様の傾向を示しているが, より柔軟なシ リコンゴムシートの場合, 搬送速度は $\phi=0^{\circ}$ および $180^{\circ}$ 付近で最大となり, $90^{\circ}$ 付近で最小となった.

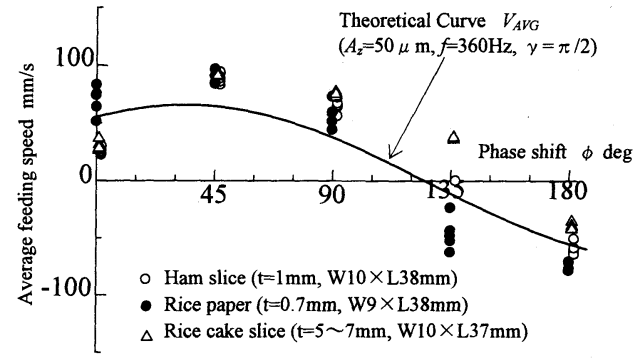

Fig.12 Feeding speed of viscous objects

搬送物が非常に軽量な場合，(5)式第 1 項の $z$ 方向への 摩擦力による搬送効果が減少し, 第 2 項の跳躍時の運 動時間がより長くなるため, 跳躍が生じ易い $y$ 方向振 幅の絶対値が最大の時に，z方向振幅が最大となる条 件で搬送速度が最大になったと考えられる。

図 12 は軟粘物を搬送対象とした場合であり，粘着 性を持つ食品（ハム，ライスペーパー，餅皮など）が 搬送可能であった。振動が作用していない面に置くと 自重でも剥れない餅皮が，搬送可能であった．搬送速

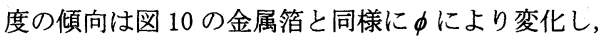
実線で示す理論平均搬送速度とほぼ近似を取っている.

搬送対象の特性の違いに関して, 薄箔材・金属箔な どでは理論平均搬送速度と近似の結果を得たことより， 図 4(b)のような搬送が実現できた，以上より，本搬送 機構では $\phi$ を可変とすることで, 異なる特性を持つ搬 送試料に対し，最大搬送速度を得ることを実現した。

4.4 振動子の並列駆動本搬送機構の場合, 搬 送面に任意の振動面形状を作り出すためには，個々の 振動子に任意のだ円振動を発生させることが必要であ る. しかし, 各振動子の駆動電圧入力に対する出力変 位の位相ずれは個々に異なるため, 前項の 4.3 搬送実 験では各振動子への位相入力を独立に調整して駆動し た.この方法では実用化の際, 搬送機構に用いる振動 子の数だけ位相調整用回路と, 駆動電圧入力のための チャンネルが必要となりコストが掛かってしまう。そ こで各振動子に同一の位相入力を与え, 別個の調整無 しに駆動し，搬送を試みる，振動子には，搬送面上に 平滑な振幅が発生可能な $\mathrm{T}$ 字型を用いた. 各振動子に は最大で $\pm 15^{\circ}$ 程度の出力変位の位相ずれが存在する

図 13 に横部材の搬送面付近を $\mathrm{CCD}$ 顕微鏡により撮 影した，だ円振動の軌跡を示す. 並列駆動では基準の 振動子に対し, 他の振動子のだ円形状がずれてしまう. 図 14 に搬送速度の変化を示す. 試料の搬送方向長さ $6 \mathrm{~mm}$ の場合, 試料は個々の振動子に 1 つずつ接触し て搬送されるため, 各振動子が発生するだ円振動形状 に多少の差異があっても搬送可能で, その傾向より跳 

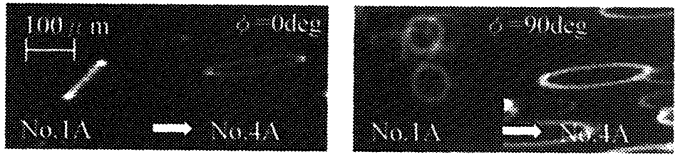

Fig.13 Elliptic vibration

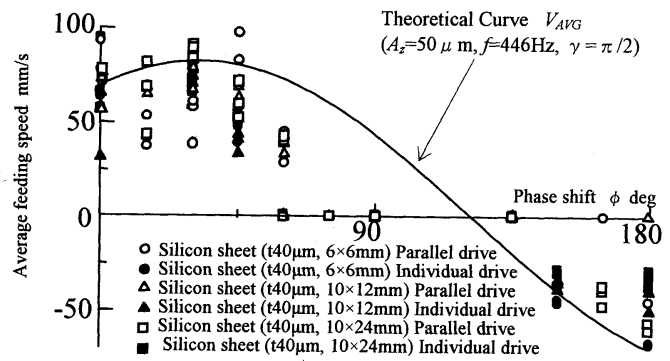

Fig.14 Feeding speed with parallel drive

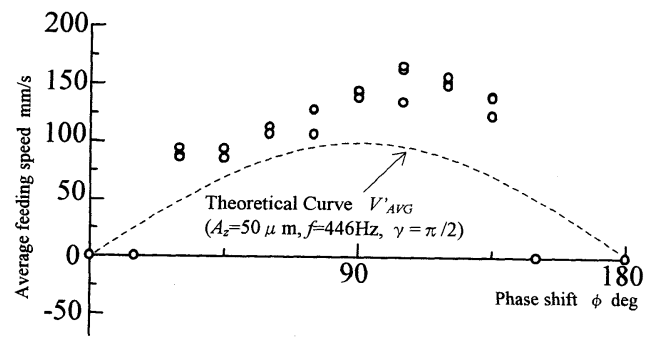

Fig.15 Feeding of adsorbent objects

躍が生じていると考えられる．搬送試料が長くなると 個々のだ円振動の差異が平滑化され, 長さ $24 \mathrm{~mm}$ の場 合では，理論平均搬送速度に比較的近い傾向を示した．

これより，並列駆動の場合でも，個々に位相ずれを 調整する駆動方法とほぼ同じ搬送速度を実現できる。

\section{5 吸着性を持つ搬送物への適用搬送困難物} とされる対象には前述のように非常に薄い，あるいは 柔らかいために搬送力が搬送物に作用しないことで搬 送不可となったり，搬送物が容易に損傷してしまうも のがあるが，一方で対象が搬送面に吸着し搬送不可亡 なるものもある．吸着の原因は静電力や搬送物自体が 吸着性を有することなど様々であるが，ここでは接着 面を有するビニールテープを用い，強力な吸着力を持 つ対象の搬送を試みる，振動子には T字型を用いた。

接着面を搬送面に向けた場合, 静的な状態では搬送 面に吸着してしまうが, 振動が発生した状態では吸着 せずに搬送が可能であった．これは，y 軸方向への振 動が搬送試料をはじき上げ，試料が搬送面に強く吸着 する以前に分離し，かつ搬送力を与えていることによ るものである. また搬送速度は，図 15 に示すように $90^{\circ}$ 付近で最大となった。 これは, 接着面を搬送面側 としているため, 非常に吸着力が大きく, 常に搬送物 が搬送面に接触し，搬送面と同じ速度となるため，平
均搬送速度は $V_{A V G}^{\prime}=2 A_{z} \omega(\sin \phi \sin \gamma) / \pi$ となる傾向に近 づいたためと考えられる.

このような吸着力の大きい対象を搬送する場合, 心゙ ルトコンベア等では搬送物を搬送面から剥がす作業が 必要となり, 従来の剛体フィーダでは移動させずには じき上げたまま，その場で停止させることができない， 本機構では, $z$ 方向振幅が 0 の状態で $y$ 軸方向のみを 駆動した場合，搬送試料が搬送面に貼りつくことなく， その場で停止させることも可能であった.

\section{5. 結言}

本報では，任意のだ円振動を発生できる振動子を複 数個組み合わせることで, 搬送困難物とされている微 小・薄䇴材および軟粘物が搬送可能な群体搬送機構を 開発した，その結果を以下にまとめる.

- 搬送困難物とされる, 厚さ $1 \mu \mathrm{m}$ までの薄箔材や, 軟粘性を持つ搬送物を損傷せずに搬送できた。

・搬送物は特性の違いにより，搬送速度が最大とな るだ円振動の傾きを持つことが分かる.

・搬送物が金属箔や軟粘物の場合, $\phi=45^{\circ}$ 付近で 約 $90 \mathrm{~mm} / \mathrm{s}$ の最大搬送速度を得て，搬送理論とも 近い結果を得た.

・ シリコンゴムシートなどの薄い柔軟物では $\phi=0^{\circ}$ 付近で約 $80 \mathrm{~mm} / \mathrm{s}$ の最大搬送速度を得て, 搬送理 論に対し，跳蹋の影響が大きい結果となった.

・駆動方法を並列駆動としても，独立に位相を制御 する方法に比べ，ほぼ同じ搬送速度を得た。

\section{謝辞}

本研究の遂行にあたり, 協力された当時の学生, 堀 田秀和氏 (現・(森アライドテック)，涉井将興氏 (現・CKD(侏)， 日南敦史氏 (現・住友エール(侏) に感謝致します。

\section{文献}

(1) Ryu, K. et al., Modeling of ICPF Actuaotr (1st Report), Transactions of the J. S. M. E., Series C, Vol.62, No.598 (1996), pp.2299-2305.

(2) Hiroshige, M. et al., Manipulation of Deformable Objects with Vision and Force Sensors, Preprints of the Annual Conference of R. S. J., (2000), pp.637-638.

(3) Makoto, T., The Present Microfactory Study, Science of Machine, Vol.53, No.3, (2001), pp.338-344.

(4) Tohru, S. et al., An Absorption of Coupled Vibration for The Colony Type Feeder with Pair Resonator, Transactions of the J. S. M. E., Series C, Vol.71, No.710 (2005), pp.2883-2887.

(5) Sakiichi, O. et al., Vibratory Conveying by Elliptical Vibration (3rd Report), Journal of the Japan Society of Precision Engineering, Vol.40, No.10 (1974), pp.840-845.

(6) Tohru, S. et al., Motion Characteristics of Loop Type Elliptic Resonator, Transactions of the J. S. M. E., Series C, Vol.69, No.4 (2003), pp.564-569. 